\title{
Thoracic Myelocele
}

National Cancer Institute

\section{Source}

National Cancer Institute. Thoracic Myelocele. NCI Thesaurus. Code C99128.

Herniation of spinal cord tissue and meninges through a defect in the thoracic region of the vertebral column. The protrusion of the tissue is flush with the level of the skin surface. 